\title{
Extensive Reading in Foreign Language Classes
}

\author{
Nabaraj Neupane
}

\begin{abstract}
Extensive reading (ER) has been advocated for having numerous benefits and values to foreign language classes. The Faculty of Education, Tribhuvan University has prescribed a wide range of textbooks, reference materials, and web-based materials, especially for Masters' students. Besides, these learners are required to read out-of-the-course materials, too. These contexts call for extensive reading on the part of the learners. Based on this background, the present study aimed to explore the learners' choice for reading materials, their purposes of reading, and the expected teacher roles. The study followed the survey research design. The respondents were $100 \mathrm{M} . \mathrm{Ed} .1^{\text {st }}$ and $2^{\text {nd }}$ year English students of the academic year 2014-15 A.D. of Prithvi Narayan Campus, Pokhara. The respondents preferred easy, interesting, informative and enjoyable materials to read; their objective of reading was to obtain general information; and they expected teachers to be prompter, participant, counselor, and role model.
\end{abstract}

Keywords: Extensive reading, materials, objectives, teacher roles

\section{Introduction}

The term 'Extensive Reading' was introduced by Palmer in 1917, distinguishing it from intensive reading in terms of the amount of reading, degree of depth, and the extent of comprehension. ER is founded in Krashen's (1982 \& 1985) Input hypothesis which shows the necessity of comprehensible input for second language acquisition; and pleasure hypothesis which claims that the enjoyable activities provide comprehensible input and lower affective filters. ER is also associated to the Book Strap hypothesis which asserts on learners' initial successful experiences; and the Flow theory which concedes learners' deep involvement in reading (Chien \& Yu, 2015).
Extensive reading (ER) is an approach to reading in which the readers enter into the text for obtaining pleasure and general information. ER is useful for setting reading habit and so it does not call for teacher's assistance in general. The readers can select the text themselves independently and read rapidly in a bird's eye-view. This is evidenced in Rivers" (1968) words, "The purpose of the extensive reading programme will be to train the students to read directly and fluently in the foreign language for his own enjoyment without the aid of the teacher (p. 229)." Thus, ER is also called independent rapid reading. For such a faster activity, silent reading is advisable, in which a good reader's eyes move fast in the text. Therefore, ER is "reading in 
quantity" and is intended to "develop good reading habits, to build up knowledge of vocabulary and structure, and to encourage a liking for reading" (Richards, Platt, \& Weber, 1985, p. 100). Supporting these views, Harmer (2008a) purports that "a teacher encourages students to choose for themselves what they read and to do so for pleasure and general language improvement" (p. 283). Further, Extensive Reading Foundation (ERF, 2011) has put forth the view that in ER, the students "read quickly and enjoyably with adequate comprehension so they don't need a dictionary" (p. 1). ERF also labels ER as "individualized/self-selected reading", "sustained silent reading", or "drop everything and read" (p. 3). Thus, ER means: (i) to read for pleasure and information, (ii) to read without the help of the teacher, (iii) to read silently and quickly, (iv) to read without using a dictionary, (v) to read for setting habit, (vi) to encourage liking for reading, and (vii) to read for gaining taste of foreign language.

There is a good rationale to encourage learners to read extensively. ER, which is also considered one of the vital $21^{\text {st }}$ century skills, is essential to develop good readers overall. When the readers read extensively in a foreign language, they can improve reading fluency, and build new vocabulary knowledge and structure. ER allows learners to improve their listening, speaking and writing abilities, too. ER also develops positive attitudes, and increases motivation and self-confidence in foreign/second language (Ono, Day \& Harsch, 2004; Neupane, 2005; \& ERF, 2011). In an empirical literature, Kalengkongan (2012) has exhibited benefits of ER in terms of spoken and written performance, learners' attitudes and fluency, spelling, vocabulary, grammar, and text structure. In the similar reviews, Chien and Yu (2015) have observed impacts of ER on the following aspects: learners at different levels/contexts, both
L1 and L2, receptive and productive skills, general language competence, affective domains, learners' confidence and the like. These reviews give impetus to claim that ER is important to trace out the avenues to enter into the fertile ground of knowledge.

For encouraging ER, different tips and principles have been forwarded by several scholars. One of them is a set of top ten principles recommended by Day and Bamford (2002, pp. 2-6)), out of which, the first, the second and the third claim that ER materials should be easy and within the readers' comfort zone. Availability of the variety of materials encourages readers to follow a flexible approach. Then, the readers enjoy freedom of choice of the reading materials. The fourth, the sixth, the ninth, and the tenth indicate necessary conditions for encouraging ER. The readers should be provided with: opportunity and incentive to read more, chance for reading as an end itself, and allow the readers to go with "reading gain without pain" ( Day\& Bamford, 1998, p. 121). Further, the teachers should be readers themselves as "reading is caught, not taught" (Nuttall, 1996, p. 229). The fifth principle exhibits the purposes of ER, and the seventh and the eighth demonstrate the silent, individual and fast nature of ER. Therefore, ER is a silent, individual and fast reading, in which fluency is a key for extensive reader.

Following these ten principles, Ono, Day and Harsch (2004) have posited these ten tips for reading extensively: read more, read easy books, read interesting books, re-read interesting books, read for general understanding, skip the difficult words, avoid using dictionaries, expand reading comfort zone, set reading goals and keep a reading $l o g$, and enjoy reading. These tips show that ER means learning to read but not reading to learn. The former refers to extensive reading whereas the latter to intensive reading. Since ER is a quantitative 
type of reading, purposes and materials are important. Using dictionaries to find the meaning of unfamiliar words is time consuming and this activity reduces reading speed. That is why, such words should be skipped for general understanding and the use of dictionary is discarded. Regarding the type of materials for ER, Neupane (2005) has also observed that materials for ER should be easy, pleasing, striking, resourceful, informative, interesting, and easy. If the text possesses these features, he purports, learners are encouraged to read extensively. However, not only materials but also settings and tasks play crucial role for ER. Tuning this view, Harmer's (2008a) advice is that learners should be provided with "appropriate materials, guidance, tasks, and facilities" (p. 283). Furthermore, the following four factors contribute to the success of ER: library, choice, feedback and time (Harmer, 2008b).

These delineations pave me a way to envisage into appropriate materials and goals to ER, expected teacher roles, and task to be done by the learners. Accordingly, this study aims to explore the nature of appropriate materials to ER, expected teacher roles, and reasons for reading extensively.

\section{Methodology}

Since this study focused on learners' needs and interests towards extensive reading (ER), I adopted the survey research design. For the execution of this design, I selected one hundred students studying English at M. Ed. $1^{\text {st }}$ and $2^{\text {nd }}$ year in Prithvi Narayan Campus, Pokhara as a census because they were regularly present in their classes. The selected respondents were observed for their concepts and behaviours towards reading prescribed books, references, and additional/supplementary materials extensively, which are mentioned in M. Ed. English Syllabus of annual exam system of T. U. The tool for collecting data was piloted questionnaire (Appendix A), which consists of five point Likert scale (Kumar, 2006) as SA- Strongly agree, A- Agree, NANDNeither agree nor disagree, D- Disagree, and SD-Strongly disagree. Of these, SA and A were treated as positive responses, SD and D as negative ones, and NAND as undecided ones. The data were collected in three parameters such as materials, objectives, and expected teacher roles. The study followed descriptive-analytical approach for the discussion/interpretation of results. Therefore, the collected data were presented, analysed, and interpreted based on the three domains respectively by means of tables to draw inferences.

\section{Results and discussion}

The collected data were presented, analysed, and interpreted in terms of three parameters such as reading materials, objectives, and expected teacher roles, which reflected major needs, interests, concepts and behaviours of the learners towards ER.

\section{Reading materials}

As the main purpose of ER is to read in quantity, reading materials should be motivating to the readers. This study also showed that the respondents preferred easy $(65 \%)$, interesting $(80)$, informative $(80 \%)$, and amusing/enjoyable (85\%) materials for ER (Table 1). These data justify the claim that ER aims to please and inform the readers. These data also confirm that learners read only if the materials are within their comfort zone. The respondents showed their tendency to read accessible $(70 \%)$ materials which are based on their needs, tastes, and interests $(90 \%)$. This exhibits that the materials should be not only interesting and informative but also 
accessible to the learners. It implies that if the learners have to wander, they cannot be motivated in reading such materials. Further, encroached, assigned, and sophisticated reading materials distracted the learners' interests. Therefore, reading materials should be captivating and easily accessible for learners.

Table 1: Extensive reading materials

\begin{tabular}{|lccccc|}
\hline $\begin{array}{l}\text { Reading materials } \\
\text { should be: }\end{array}$ & SA & A & NAND & D SD \\
\hline Easy & 45 & 20 & 15 & 15 & 5 \\
\hline Interesting & 65 & 15 & 5 & - & - \\
\hline Resourceful & 10 & 15 & 70 & 5 & - \\
\hline Informative & 28 & 62 & 5 & 5 & 5 \\
\hline Amusing/ Enjoyable & 30 & 55 & 2 & 8 & 5 \\
\hline Striking & 5 & 8 & 80 & 2 & 5 \\
\hline Innovative & 2 & 7 & 75 & 5 & 11 \\
\hline Accessible & 20 & 50 & 15 & 5 & 10 \\
\hline
\end{tabular}

Table 1, furthermore, demonstrates that the respondents were undecided towards resourceful $(70 \%)$, striking $(80 \%)$, and innovative $(75 \%)$ materials. This shows that even M. Ed. students are not motivated and conscious to read resourceful and innovative materials, which is indicative of the fact that even the higher level learners prefer easy and informative materials. Therefore, this study also justifies the theoretical stances asserted in Day and Bamford (1998 \& 2002) and Chien (2015), and empirical evidence presented in Kalengkongan (2012).

\section{Reading objectives}

Unlike in the domain of reading materials, the respondents showed variations in responses in terms of ER objectives (Table $2)$. They read for obtaining general information $(60 \%)$, but not for getting pleasure $(60 \%)$. The results show controversy as it justified one major ER objective, i.e. reading for general information but falsified the other, i.e. reading for pleasure. One possible reason behind this is that the respondents read for information as they were test-oriented and accordingly, they preferred the texts which were inevitable for their examinations.

Table 2: Objectives of extensive reading

\begin{tabular}{|lcccc|}
\hline ER is aimed to obtain: & SA & A & NAND & D SD \\
\hline Pleasure & 17 & 13 & 10 & 4020 \\
\hline General information & 20 & 40 & 17 & 1310 \\
\hline Reading habit & 5 & 10 & 60 & 187 \\
\hline Reading fluency & 5 & 18 & 59 & 108 \\
\hline Other skills & 12 & 18 & 68 & 57 \\
\hline $\begin{array}{l}\text { Vocabulary and } \\
\text { structure enhancement }\end{array}$ & 5 & 9 & 30 & 3917 \\
\hline
\end{tabular}

The respondents were undecided for using ER in order to build reading habit $(60 \%)$, increase reading fluency (59\%), develop listening reading and writing skills (68\%), and enhance vocabulary and structure (50\%). These results can be interpreted to mean that even the masters' level students are unaware of the proficiency level to be acquired by the good readers. Until the learners obtain the general proficiency level in ER, they cannot develop these skills. Therefore, the respondents' ER proficiency level was poor. These delineations show that the theoretical stances of ER cannot be backed up by this study in terms of the objectives of reading extensively.

\section{Expected teacher roles}

Teachers are dynamic powers of whole educational system as they are mobilisers of educational policy into the learners' level. They are at the core of teaching learning process. To put in Neupane's (2016) words, "Teachers are at the centre of concentric rings of education system. [...] the figure of teacher reflects some 
spectra, which are essentials for professionalism" (p. 261). Out of some spectra, teacher roles are vital for learners. For this study, I have selected teacher roles from Kumaravadivelu's (2003, p. 2) concept "strategic thinkers/practitioners" and of Farell and Jacobs' (2010, p. 2) "co-learners". Table 3 shows the tested expected teacher roles in ER.

\section{Table 3: Expected teacher roles}

\begin{tabular}{|lccccc|}
\hline $\begin{array}{l}\text { Learners want ER } \\
\text { teachers to be: }\end{array}$ & SA & A & NAND D & SD \\
\hline Authority/Controller & 10 & 12 & 28 & 50 & 10 \\
\hline Prompter/Catalyst & 33 & 27 & 11 & 19 & 10 \\
\hline Organizer & 5 & 23 & 17 & 25 & 30 \\
\hline Participant & 24 & 38 & 18 & 12 & 8 \\
\hline Administrator & 9 & 21 & 15 & 28 & 27 \\
\hline Initiator & 12 & 18 & 53 & 14 & 3 \\
\hline Counsellor & 22 & 33 & 10 & 25 & 10 \\
\hline Role model & 25 & 37 & 28 & 4 & 6 \\
\hline
\end{tabular}

Table 3 exhibits that teachers were expected to be prompter/catalyst $(60 \%)$, participant $(62 \%)$, counselor $(55 \%)$, and role model $(62 \%)$. On the other hand, teachers were rejected as authority/ controller $(60 \%)$, organizer $(55 \%)$, and administrator $(55 \%)$. However, teacher's role as initiator (53\%) was undecided.

The results showed that the respondents needed some "agency" (Harmer, 2008b, p. 21 ), i.e. they wanted to take responsibility for ER. They required relative freedom and responsibility for their sustained drive for reading extensively. Since the respondents desired to be self-administrators and selforganisers, they should have right to choose materials for "joyful reading" (Harmer, 2008 b, p. 110), and they can select and organize reading materials themselves. However, the results also exhibited that the respondents wished teachers to prompt and to counsel for selecting and organizing these materials. Further, teachers were expected to be co-readers and role models for the learners.

\section{Conclusion}

This study testified respondents' ER concepts and behaviours in terms of reading materials, objectives, and expected teacher roles. The reading materials were preferred to be easy, interesting, informative and pleasing. It implies that ER materials should be easily accessible to the learners. They should also be in perfect harmony with the learners' needs, tastes, and interests. In foreign language classes, the learners were observed not to have motivation for resourceful, striking, and innovative materials. Regarding objectives, the learners read for information because they were exam-oriented. So, they showed inclinations to be informationcollectors rather than extensive readers. They did not read for pleasure and entertainment and so reading for them was only for passing exam rather than gaining true knowledge and obtaining pleasure simultaneously.

Furthermore, the learners did not desire to set reading habit, develop reading fluency, and used ER for enhancing vocabulary and structure of foreign language. In terms of teacher roles, the learners expected them to be prompters, counselors, participants, and role models. They did not expect teachers to be authority/controller, which is traditional role type. In a nutshell, the learners desired to take responsibility for selecting and organizing ER materials. Despite this, teacher role was facilitative of their extensive reading ability.

However, it is early enough to conclude this way as this study had limitations in data, time, and study area. This small scale study, yet, can leave trace-effects for further studies in this field of extensive reading. 


\section{References}

Chien, C. K. C., \& Yu, K. J. (2015). Applying extensive reading to improve unmotivated learners, attitudes toward reading in English. International Journal of Learning, Teaching, and Educational Research, 13 (2), 1-25.

Day, R. R., \& Bamford, J. (1998). Extensive reading in the second language classroom. Cambridge: Cambridge University Press.

Day, R. R., \& Bamford, J. (2002). Top ten principles for teaching extensive reading. Reading in a Foreign Language, 14 (2). Retrieved from http:// nflrc.hawaii.edu/rf/

Extensive Reading foundation [EFR] (2011). Guide to extensive reading. Retrieved from www.erfoundation.org

Farrell, T. S. C., \& Jacobs, G. M. (2010). Essentials for successful English language teaching. London \& New York: Continuum.

Harmer, J. (2008a). The practice of English language teaching ( $4^{\text {th }}$ ed.). London: Pearson Longman.

Harmer, J. (2008b). How to teach English. London: Pearson Longman.

Kalengkongan, D. N. (2012). Students' attitudes towards extensive reading. An undergraduate thesis, Satya Wacana Christian University, Salatiga.

Kumar, R. (2006). Research methodology: A step-by-step guide for beginners (2nd ed.). New Delhi: Dorling Kindersley.

Kumaravadivelu, B. (2003). Beyond methods: Macrostrategies for language teaching.
New Haven \& London: Yale University Press.

Neupane, N. (2005). Encouraging extensive reading. Educational Mirror, 4 (1), 11.

Neupane, N. (2016). Spectra of teachers: essentials for professionalism. Pragyamanch, 29 (14), 261-269.

Nuttall, C. (1996). Teaching reading skills in a foreign language ( $2^{\text {nd }}$ ed.). Oxford: Heinemann.

Ono, L., Day, R. R., \& Harsch, K. (2004). Tips for reading extensively. Forum, 42 (4), 12-18.

Rivers, W. (1968). Teaching foreign language skills. Chicago: University of Chicago Press.

Richards, J., Platt, J., \& Weber, H. (1985). Longman dictionary of applied linguistics. Essex, England: Longman.

The author: Nabaraj Neupane, a Reader of English Education at Tribhuwan University, is pursuing $\mathrm{PhD}$ in Translation Studies. To his credit, three dozens articles have been published in different journals. He has also published books, edited journals, translated literary texts, and presented papers in national and international conferences. His professional interests include Translation Studies, SLA, and Pragmatics. 
Appendix A

\section{Questionnaire for Students}

1 Extensive reading materials should be:

\begin{tabular}{|l|l|l|l|l|l|}
\hline & SA & A & NAND & D & SD \\
\hline Easy & & & & & \\
\hline Interesting & & & & & \\
\hline Resourceful & & & & & \\
\hline Informative & & & & & \\
\hline Amusing/ Enjoyable & & & & & \\
\hline Striking & & & & & \\
\hline Innovative & & & & & \\
\hline Accessible & & & & & \\
\hline
\end{tabular}

2 I read extensively for:

\begin{tabular}{|l|l|l|l|l|l|}
\hline & SA & A & NAND & D & SD \\
\hline Pleasure & & & & & \\
\hline General information & & & & & \\
\hline Reading habit & & & & & \\
\hline Reading fluency & & & & & \\
\hline Other skills & & & & & \\
\hline Vocabulary and structure enhancement & & & & & \\
\hline
\end{tabular}

3 What types of teacher roles do you expect for better extensive reading?

\begin{tabular}{|l|l|l|l|l|l|}
\hline & SA & A & NAND & D & SD \\
\hline Authority/Controller & & & & & \\
\hline Prompter/Catalyst & & & & & \\
\hline Organizer & & & & & \\
\hline Participant & & & & & \\
\hline Administrator & & & & & \\
\hline Initiator & & & & & \\
\hline Counsellor & & & & & \\
\hline Role model & & & & & \\
\hline
\end{tabular}

Note: SA-Strongly agree, A- Agree, NAND- Neither agree nor disagree, D-Disagree, $S D$ - Strongly disagree 